\title{
Innovation potential assessment of conceptual design alternatives during PDP
}

\author{
Juliane de Bassi Padilha, Carlos Cziulik, Paulo André de Camargo Beltrão \\ Universidade Tecnológica Federal do Paraná - UTFPR \\ e-mails: julianepadiha@uffpr.edu.br; czillik@uffpr.edu.br; beltra@@uffpr.edu.br
}

\begin{abstract}
The quest for product differentiation, associated with shortening in the product life cycle, turns innovation an indispensable element for the organizations competitiveness in the market. Therefore, it is of fundamental importance to address innovation issues during the early stages of the Product Design Process (PDP). The conceptual design stage represents, within the whole design process, a phase in which many of important decisions regarding the new product being developed are taken. Therefore, issues inherent to innovation should be examined at this stage during PDP. The study aims at defining criteria oriented to innovation that can be applied for assessing and ranking conceptual alternatives, to identify the solution that presents the highest potential to become an innovative product in the market. The criteria and subcriteria were defined with support of literature and a reverse analysis. Next, these criteria were incorporated into a working framework named the API_PC Tool. To verify the framework functionalities, an experiment was conducted in a controlled environment, which aimed at simulating a design situation involving the selection of a conceptual design solution for a specific product context. Following, a questionnaire was applied to the participants in order to identify their perception regarding the usage of the proposed approach, as well as, its ability to identify the innovation opportunities during the early stages of PDP.
\end{abstract}

Keywords: innovation, conceptual design, selection of design alternatives.

\section{Introduction}

Considering the current scenario of national and international competition, companies must improve their competitiveness in order to keep the business running. In addition, the customers are seeking for products that can go beyond the satisfaction of their needs, presenting some features that differentiate them from the concurrency. It has also been observed that new products are being launched at smaller intervals due to shortening in their life cycle (NANTES; ABREU; LUCENTE, 2006; CORAL; OGLIARI; ABREU, 2008).

Those companies that opt to keep the same design procedures, working with either products or technologies that are obsolete, tend to lose their market share. Nantes, Abreu and Lucente (2006) mention that development of new products are vital for the organization competitiveness.

Marinho et al. (2016) highlight that innovation is an important variable in the current economic scenario. This is an essential element for organizations that aim at maintaining competitiveness by adding value to their products. Similarly, Bagno, Leivab And Oliveira (2016) mention the relevance of tools for the diagnosis of innovation as a way to contribute to the competitiveness of organizations.

Thus, it is evident that innovation is considered as an indispensable element within the PDP. In this way, innovation should be addressed in a systematized and not as a casual occurrence during the whole process (PAHL et al., 2005; ROZENFELD et al., 2006; CORAL; OGLIARI; ABREU, 2008; BACK et al., 2008).

Among the phases that integrate the PDP, it is the conceptual design stage which usually defines the solution principles for the final product. Therefore, addressing innovation at this stage contributes to the differentiation of the product to be developed, leveraging the competitiveness of organizations. From this context, this paper aims to present a set of criteria (dismembered in subcriteria) oriented to the innovation that can support the selection of conceptual alternatives, at early stages of the design process. The framework and procedures developed were encompassed into a tool named API_PC (PADILHA, 2008).

This paper is organized as follows. Section 2 presents how innovation is examined and related to PDP by means of an extensive literature review. The assumptions, criteria description, API_PC Tool structure and guidelines are described in Section 3. A controlled experiment, illustrating the main features of the proposed approach, as well as, the obtained results can be seen in Section 4 . Final considerations are presented in Section 5, highlighting the contributions of the present study. 


\section{Innovation approaches considering the pdp context}

The literature presents several definitions and concepts for the term "innovation". The Oslo Manual introduces a general definition for innovation which states:

[...] innovation is the implementation of a new or significantly improved product (good or service), or a process, or a new marketing method; or a new organizational method in business practices, in the organization of the workplace or in external relations [...] (ORGANIZAÇÃO..., 2005, p. 55).

Zawislak et al. (2008) characterize innovation as the application of knowledge, which is capable of producing technical or organizational changes that offer advantages to companies. The applied knowledge may be new to the company, but not necessarily to its competitors, to the market or to the world (ZAWISLAK et al., 2008; PUERTO, 1999). This degree of novelty drives incremental innovations to the core of the innovation process in developing countries. Similarly, Xie et al. (2016) argue for the importance of developing knowledge for innovation activities highlighting the need to use it effectively.

Scherer and Carlomagno (2009) emphasize that new ideas bring results and great returns for companies. "Innovation means continually seeking growth and leadership. It involves creativity, perspiration, persistence, management and risk" (SCHERER; CARLOMAGNO, 2009, p. 8).

Innovation encompasses a multidisciplinary field in which the PDP acts as a central element since the decisions taken in every stage influence the expected result, which is innovation (ZABALA-ITURRIAGAGOITIA, 2012). Thus, the importance of a systematized process within the PDP that contemplates the quest for innovation allows the company to recognize opportunities, establish priorities in its projects and improve issues related to time and costs. "For organizations to remain long in the market and launch new products and services in a systematic and continuous way, they need to have a proper approach for managing innovation [...]" (CARVALHO; REIS; CAVALCANTE, 2011, p. 55). Despite this, it is verified a high rate of failure in new products released to the market. This fact is justified by the inconsistent application of techniques, models and tools that guide the PDP and its links with innovation issues (SALGADO et al., 2010).

The structured PDP, according to Back et al. (2008), is composed of different phases: i) informational design; ii) conceptual design; iii) preliminary design; and iv) detailed design. The conceptual design stage defines solution principles, as well as, the basic features of form and function that will create the identity of the final product (BAXTER, 2000; BACK et al., 2008).
The selected design alternative during the conceptual design stage is an approximate description of the technologies, principles of operation and formal proposal of the product being developed. The conceptual design phase comprises the search, creation, representation and selection of solutions (BACK et al., 2008). The main difficulty associated with this phase is that technical information are still limited and of abstract nature (ROZENFELD et al., 2006).

The process of selecting alternatives allows to identify which concepts will be developed as well as which have to be abandoned. Therefore, according to Toh and Miller (2015), this can be considered a gatekeeper of creative ideas that can result in innovative products. Li et al. (2010) highlight the fact that errors at this stage can compromise 70 to $80 \%$ of investment in the whole product development. Therefore, a selection process driven to innovation can recognize creative and differentiated ideas, with potential of innovation.

Pahl et al. (2005) state that there is no completely secure/safe method that prevents wrong decisions from being taken during PDP. However, they reiterate that the use of systematic selection methods leads to a better management of this activity.

Some authors have examined mechanisms that aim to assist the design team in the process of generation and selection of alternatives. Yilmaz and Seifert (2011) suggest the use of 21 heuristics in the process of product design as a way of stimulating new solutions or transforming an existing concept. Back et al. (2008) present attributes that can guide the indication of criteria for the selection of design alternatives. These attributes are classified in: i) basic attributes; ii) life cycle attributes; and iii) specific attributes. Sarkar and Chakrabarti (2011) propose a way of evaluating the novelty of a product by comparing it with other products available that perform the same function. In the SAPPhIRE Model (SARKAR; CHAKRABARTI, 2011) the degree of novelty of a product is ranked as being: high, medium or low.

In the process of selecting alternatives, the criteria adopted should be clear, independent, accurate and applicable in the same way to all design concepts in the solution set (PAHL et al., 2005; BACK et al., 2008).

The mentioned approaches establish generic mechanisms and conditions for a design alternative selection. The search for the solution that presents greater innovation potential requires the identification of innovation driven criteria that allow to define evaluation parameters on how a design solution is potentially innovative when compared to the others in the set.

Therefore, the following section presents the API_PC framework and related tool (PADILHA, 2008), which describes a process for applying criteria oriented to 
innovation for selecting conceptual alternatives at the conceptual design stage.

\section{Analysis of the innovation process by the api_pc tool}

The API_PC (Assessment of Innovation Potential at Conceptual Design Stage) framework and respective tool, presented by Padilha (2008), identified six innovation-oriented criteria through a reverse analysis of five products from several industry segments. In these products elements related to the scope of innovation were recognized and then, characterized.

The selection of these products was based on the response from the customers, their impact on the market and awards received for their innovations.

The identified criteria that could be considered an innovation driver for that set of products were: i) ergonomics; ii) form; iii) function; iv) manufacturing; v) technology; and vi) transportation. With the objective of verifying the consistency of the mapped criteria, a new reverse analysis was conducted following the framework proposed by Padilha (2008). Table 1 presents the selected product: the Kärcher High Pressure Washer K2500, developed by a Design Office in Brazil (QUESTTO|NÓ, 2016).
The reverse analysis conducted for providing the support and reasoning embedded into the API_PC framework and tool allowed the identification of drivers of innovation (here, called criteria). The new reverse analysis performed with the high pressure washer followed the same approach as found in Padilha (2008) and allowed to identify the occurrence of four of the six criteria originally set. This indicates the relevance of the product chosen and its analysis as presented in Table 1 .

The six criteria were divided into subcriteria and submitted to the examination of experts (PADILHA, 2008), which allowed to define weights and values. Table 2 shows the respective deployment.

Once this examination was concluded and to facilitate the process of assessing the alternatives in the solution set, a matrix was structured considering: i) the set of criteria; ii) the correspondent set of subcriteria; and iii) respective weight values for each subcriterion (computed from the data collected in the field survey). The layout of the matrix was then established and implemented as an electronic spreadsheet. In the first column are the criteria (in alphabetical order). The second column includes an acronym for each subcriterion to facilitate its identification. The third column contains the description of the subcriterion.

Table 1. Reverse analysis of Kärcher High Pressure Washer K2500.

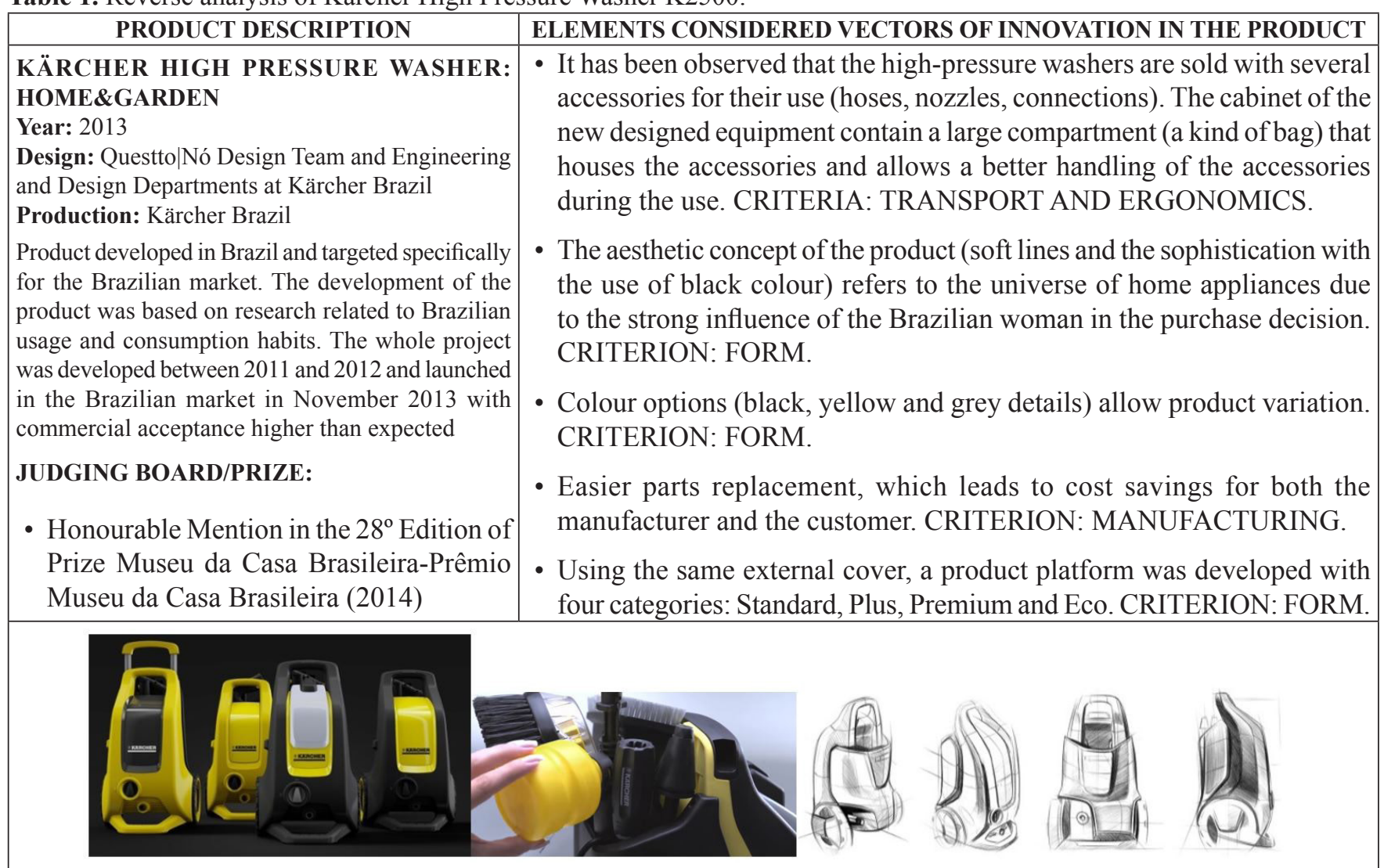

Source: Adapted from: Prêmio Museu da Casa Brasileira (2014) and Questto|Nó (2016). 
Table 2. Criteria and respective deployment, as innovation drivers.

\begin{tabular}{|c|l|}
\hline CRITERION & \multicolumn{1}{|c|}{ SUBCRITERION } \\
\hline Ergonomics & The alternative has a distinct ergonomic design from the existing product in the market. \\
\hline \multirow{5}{*}{ Form } & The alternative differs significantly from other existing products. \\
\cline { 2 - 3 } & $\begin{array}{l}\text { The alternative presents some characteristic that turns it unique (e.g. use of cultural elements, analogy with elements } \\
\text { of nature, amongst others). }\end{array}$ \\
\cline { 2 - 3 } & The alternative presents some level of customization (colours, compositions, textures). \\
\cline { 2 - 3 } & The alternative is modular. New components can be added in later editions of the product. \\
\hline \multirow{4}{*}{ Function } & The alternative implements some completely new function. \\
\cline { 2 - 3 } & The alternative implements additional functions, non-existent in similar products. \\
\cline { 2 - 3 } & The alternative implements the same function as the like products, but in a significantly different way. \\
\hline \multirow{3}{*}{ Manufacturing } & The alternative aims at simplifying or significantly improving the manufacturing process of the future product. \\
\cline { 2 - 3 } & The alternative foresees the use of a new material, which has never been used before in that development context. \\
\cline { 2 - 3 } Transport & The alternative foresees the use of a known material, but never applied for the proposed context. \\
\hline \multirow{3}{*}{ Technology } & The alternative presents a technological attribute that differentiates it from similar products. \\
\cline { 2 - 3 } & The alternative presents a new way of packing the product in relation to the similar ones. \\
\cline { 2 - 3 } & The alternative presents a new way of transporting the product in relation to the similar ones. \\
\cline { 2 - 2 } & The alternative presents a new way of distributing the product to the market in relation to the similar ones. \\
\hline
\end{tabular}

Source: Adapted from Padilha (2008).

From the fourth column onwards, are cells that are referred to each conceptual design solutions submitted to the evaluation process (i.e. $\mathrm{C} 1, \mathrm{C} 2, \mathrm{C} 3, \ldots, \mathrm{Cn}$ ).

If the assessment design team recognizes that the proposed design solution fulfils the respective subcriterion, a mark " $X$ " must be placed in the corresponding cell. Otherwise, the cell should remain empty.

As the cells are filled, the spreadsheet is automatically updated, providing the summation of each subcriterion assigned, resulting in a net score for the conceptual design solution.

It is worth mentioning that during the evaluation process, for avoiding any type of bias and minimizing personal preferences, the design team does not have access to the net values (either partial or total) derived from the assessment of each conceptual design proposal. These values are only available at the end of the evaluation process to the Design Team Leader. The Design Team Leader then can exhibit the top part of the matrix, which shows the values assigned to each individual criterion and the overall value for the conceptual design proposal (the line highlighted in light yellow).

Table 3 contains the final layout of the API_PC computer implementation.

It is important to highlight that for producing suitable results with the use of the tool it is necessary that the conceptual design alternatives should present similar level of description an details, therefore, being comparable. Figure 1 contains a diagram which aims at guiding the task when using the proposed tool.

Specific cases may occur when using API_PC Tool, which will require some type of intervention by the Design Team Leader and the design team members. They are described next: i) none of the available cells is marked; ii) all cells are marked for all conceptual design solutions being assessed; iii) there is a draw involving two or more conceptual design solutions with identical marking; iv) there is a draw involving two or more conceptual design solutions, but involving different cells marked; v) none of the cells for a specific criterion/subcriterion is marked; and vi) only one criterion has cells marked for the conceptual design solutions. Table 4 contains the recommendations of action for the design team considering each situation just described.

Therefore, the following section describes a controlled experiment involving the usage of the API_PC tool. Also, the obtained results and respective discussions are presented.

\section{Experimental application using api_pc tool}

In this section, a replication of a real project development context illustrates the procedures for correctly using API_PC. In this design scenario, the design team is requested to assess, from a homogeneous solution set, the conceptual design solution that presents greater innovation potential.

In this way, it is possible to capture information regarding the use of the tool, as well as, the perceptions of professionals considering the selection of conceptual alternatives when the focus is the potential for innovation.

For this experimental context, were presented four conceptual design alternatives of a dental brush designed by a Design Office, based in the city of Curitiba-PR, Brazil. According to Padilha (2008), the concept design of the 
Table 3. API_PC main layout.

\begin{tabular}{|c|c|c|c|c|c|c|}
\hline \multirow{2}{*}{\multicolumn{3}{|c|}{ 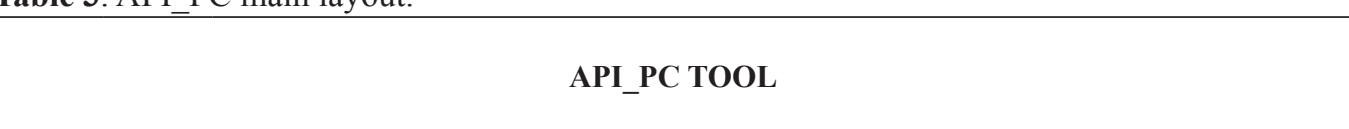 }} & \multicolumn{4}{|c|}{$\begin{array}{l}\text { CONCEPTUAL DESIGN } \\
\text { SOLUTION }\end{array}$} \\
\hline & & & C1 & $\mathbf{C 2}$ & C3 & Cn \\
\hline & & Ergonomics & 0 & 0 & 0 & 0 \\
\hline & & Form & 0 & 0 & 0 & 0 \\
\hline & & Function & 0 & 0 & 0 & 0 \\
\hline & & Manufacturing & 0 & 0 & 0 & 0 \\
\hline & & Technology & 0 & 0 & 0 & 0 \\
\hline & & Transport & 0 & 0 & 0 & 0 \\
\hline & & OVERALL SUM OF EACH CRITERION WEIGHT VALUE & $\mathbf{0}$ & $\mathbf{0}$ & $\mathbf{0}$ & $\mathbf{0}$ \\
\hline 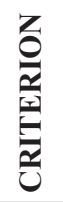 & TAG & SUBCRITERION & \multicolumn{4}{|c|}{$\begin{array}{l}\text { Mark with "X" as an } \\
\text { occurrence is identified }\end{array}$} \\
\hline $\begin{array}{l}0 \\
0 \\
0 \\
0 \\
0 \\
0 \\
\frac{\pi}{x} \\
\frac{1}{x}\end{array}$ & Eg1 & $\begin{array}{l}\text { Ergonomics: the examined design alternative has an ergonomic design that differentiates } \\
\text { it from those existing design solutions in the market }\end{array}$ & & & & \\
\hline \multirow{4}{*}{ 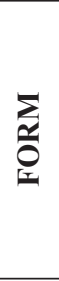 } & Fr1 & Form: the examined design alternative is significantly different from other existing products. & & & & \\
\hline & Fr2 & $\begin{array}{l}\text { Form: the examined design alternative presents some characteristic that turns it unique } \\
\text { (e.g. use of cultural elements, analogy with elements of nature, amongst others). }\end{array}$ & & & & \\
\hline & Fr3 & $\begin{array}{l}\text { Form: the examined design alternative presents a certain level of customization } \\
\text { (e.g. colours, compositions, textures). }\end{array}$ & & & & \\
\hline & Fr4 & $\begin{array}{l}\text { Form: the examined design alternative is modular. New components can be added to later } \\
\text { editions of the product. }\end{array}$ & & & & \\
\hline \multirow{3}{*}{ 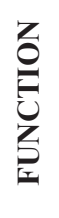 } & Fn1 & Function: the examined design alternative implements a completely new function. & & & & \\
\hline & Fn2 & $\begin{array}{l}\text { Function:: the examined design alternative implements additional functions, non-existent } \\
\text { in similar products }\end{array}$ & & & & \\
\hline & Fn3 & $\begin{array}{l}\text { Function: the examined design alternative implements the same function as similar products, } \\
\text { but in a significantly different approach }\end{array}$ & & & & \\
\hline \multirow{3}{*}{ 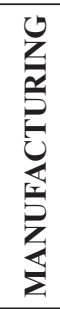 } & Mn1 & $\begin{array}{l}\text { Manufacturing: the examined design alternative aims at simplifying or significantly } \\
\text { improve the manufacturing process of the future product }\end{array}$ & & & & \\
\hline & Mn2 & $\begin{array}{l}\text { Manufacturing: the examined design alternative encompasses the use of a new material, } \\
\text { which has never been experimented before }\end{array}$ & & & & \\
\hline & Mn3 & $\begin{array}{l}\text { Manufacturing: the examined design alternative involves the use of a known material, but } \\
\text { never applied for the aimed purpose }\end{array}$ & & & & \\
\hline 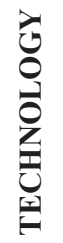 & Te1 & $\begin{array}{l}\text { Technology: the examined design alternative presents some technological attribute that } \\
\text { differentiates it from similar products. }\end{array}$ & & & & \\
\hline \multirow{3}{*}{ 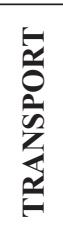 } & Tr1 & $\begin{array}{l}\text { Transport: the examined design alternative presents a new way of packaging the product } \\
\text { considering similar products in the market }\end{array}$ & & & & \\
\hline & Tr2 & $\begin{array}{l}\text { Transport: the examined design alternative presents a new way of transporting the product } \\
\text { when compared to similar products in the market }\end{array}$ & & & & \\
\hline & Tr3 & $\begin{array}{l}\text { Transport: the examined design alternative a new way of distributing the product when } \\
\text { compared to similar products in the market }\end{array}$ & & & & \\
\hline
\end{tabular}




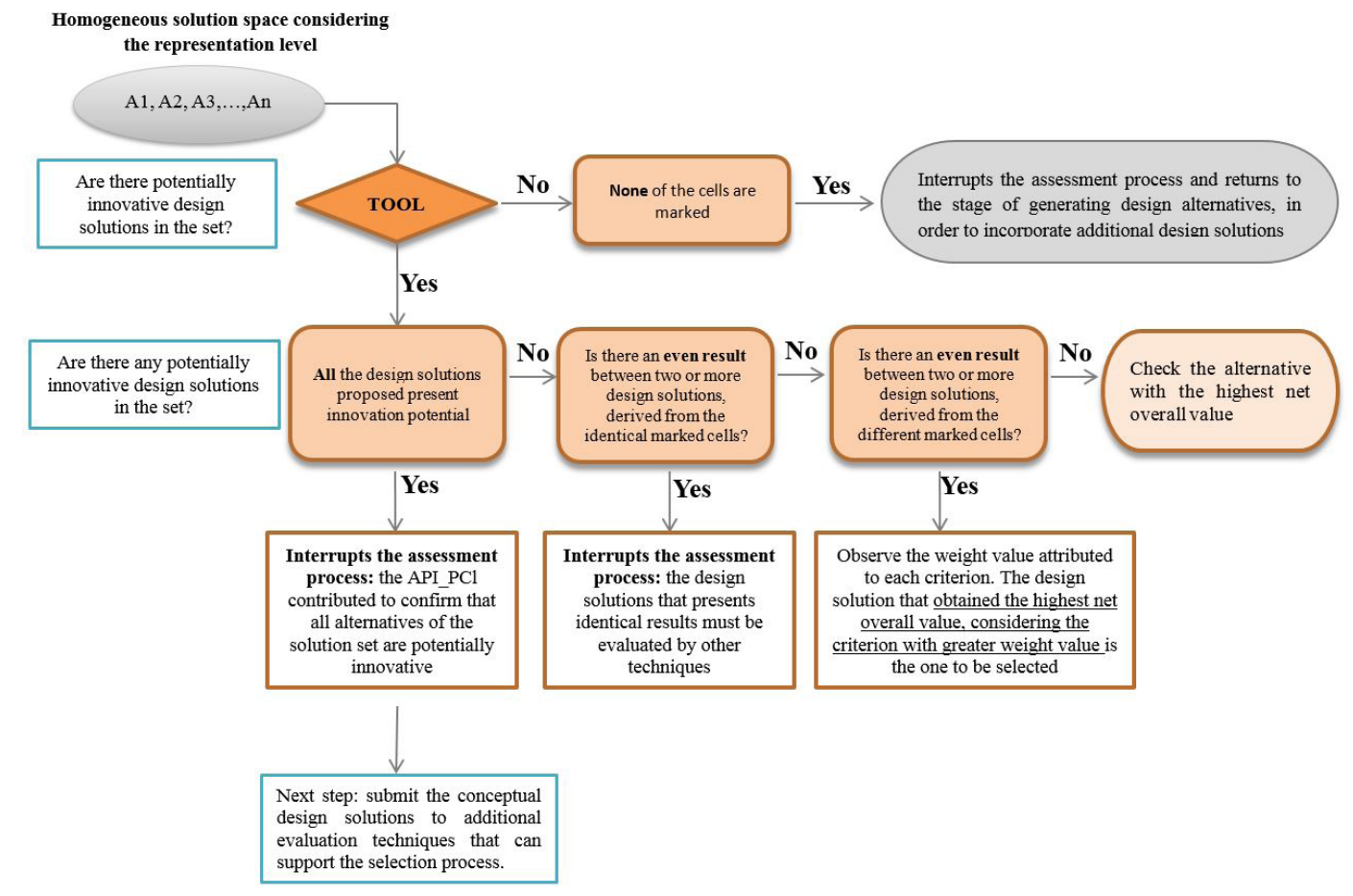

Figure 1. Guidelines for using the API_PC Tool. Source: Padilha (2008).

Table 4. API PC Tool: singular cases.

\begin{tabular}{|c|c|c|}
\hline Case & Observation & Recommendation \\
\hline None of the cells is marked & $\begin{array}{l}\text { The conceptual design alternatives in } \\
\text { the solution set do not contain elements } \\
\text { related to the criteria which would } \\
\text { consider them as innovative. }\end{array}$ & $\begin{array}{l}\text { The process of selecting the design alternatives must be interrupted and } \\
\text { the design team should re-examine the proposed design solutions. }\end{array}$ \\
\hline $\begin{array}{l}\text { All cells are marked for all } \\
\text { design alternatives }\end{array}$ & $\begin{array}{l}\text { All the alternatives of the solution set } \\
\text { might present an innovation potential. }\end{array}$ & $\begin{array}{l}\text { Forward the proposed design solutions to another assessment tools. In this } \\
\text { case, the innovation issue will be already evaluated. }\end{array}$ \\
\hline $\begin{array}{l}\text { Identical net results } \\
\text { derived from the same } \\
\text { cells marked for the } \\
\text { design solutions involved }\end{array}$ & $\begin{array}{l}\text { The results indicate that there is more } \\
\text { than one design solution in the set with } \\
\text { an innovation potential identified }\end{array}$ & Forward the proposed design solutions to another assessment tools. \\
\hline $\begin{array}{l}\text { Identical net results } \\
\text { derived from the different } \\
\text { cells marked for the design } \\
\text { solutions involved }\end{array}$ & $\begin{array}{l}\text { The weight values for each criterion } \\
\text { should be observed }\end{array}$ & $\begin{array}{l}\text { The alternative that presents higher score in the criterion with greater } \\
\text { weight value should be selected. If there is still an identical result, the } \\
\text { second criterion of greatest weight value should be observed and so on, } \\
\text { in order to select a specific conceptual design solution. }\end{array}$ \\
\hline $\begin{array}{l}\text { Not having cells marked } \\
\text { at all for one or more } \\
\text { criterion }\end{array}$ & $\begin{array}{l}\text { In this case, the criterion has no } \\
\text { significant relevance within the design. } \\
\text { It may be not properly addressed in the } \\
\text { design specifications document. }\end{array}$ & $\begin{array}{l}\text { If the criterion without any cells marked is clearly present in the design } \\
\text { specification document, the team should review the design solutions in } \\
\text { the solution set, in order to encompass features related to this criterion } \\
\text { in the design alternatives. } \\
\text { The solution set disregarded an important issue stated in the design } \\
\text { specification document. }\end{array}$ \\
\hline $\begin{array}{l}\text { Only one criterion have its } \\
\text { cells marked }\end{array}$ & $\begin{array}{l}\text { The team should verify, in the design } \\
\text { specification document, why those } \\
\text { criteria shown in the API_PC have not } \\
\text { been addressed. }\end{array}$ & $\begin{array}{l}\text { If the design specifications were fully observed, the assessment process } \\
\text { should proceed. } \\
\text { If a non-conformity is identified, the team should stop the process and } \\
\text { review the design solutions proposed. }\end{array}$ \\
\hline
\end{tabular}

Source: Adapted from Padilha (2008).

aimed product involves the attributes of a mass product with the appearance of a differentiated and value-added object.

The product must be distinct in terms of form from those sold in the market. Additionally, the bristles have to be mounted in different angles, complying with the last tendencies in the techniques of teeth brushing.

With these features, the company aimed to positioning this product in the high end of its portfolio. 
Table 5 illustrates the conceptual design alternatives and presents the general project scope which the design team must comply with.

The experiment was conducted in a controlled environment involving nine participants, in the dependencies of CITEC (Technological Innovation Centre), at UTFPR (Federal Technological University of Paraná).
The participants were divided into five groups which received a document with a brief description of each alternative to be assessed. Table 6 presents the profile of the participants, the division of the groups and the proposed assessment task.

The Group G1, was set to be the so-called "control group" and was allocated in a separate room. The participants of this

Table 5. Conceptual design solutions and their general requirements.

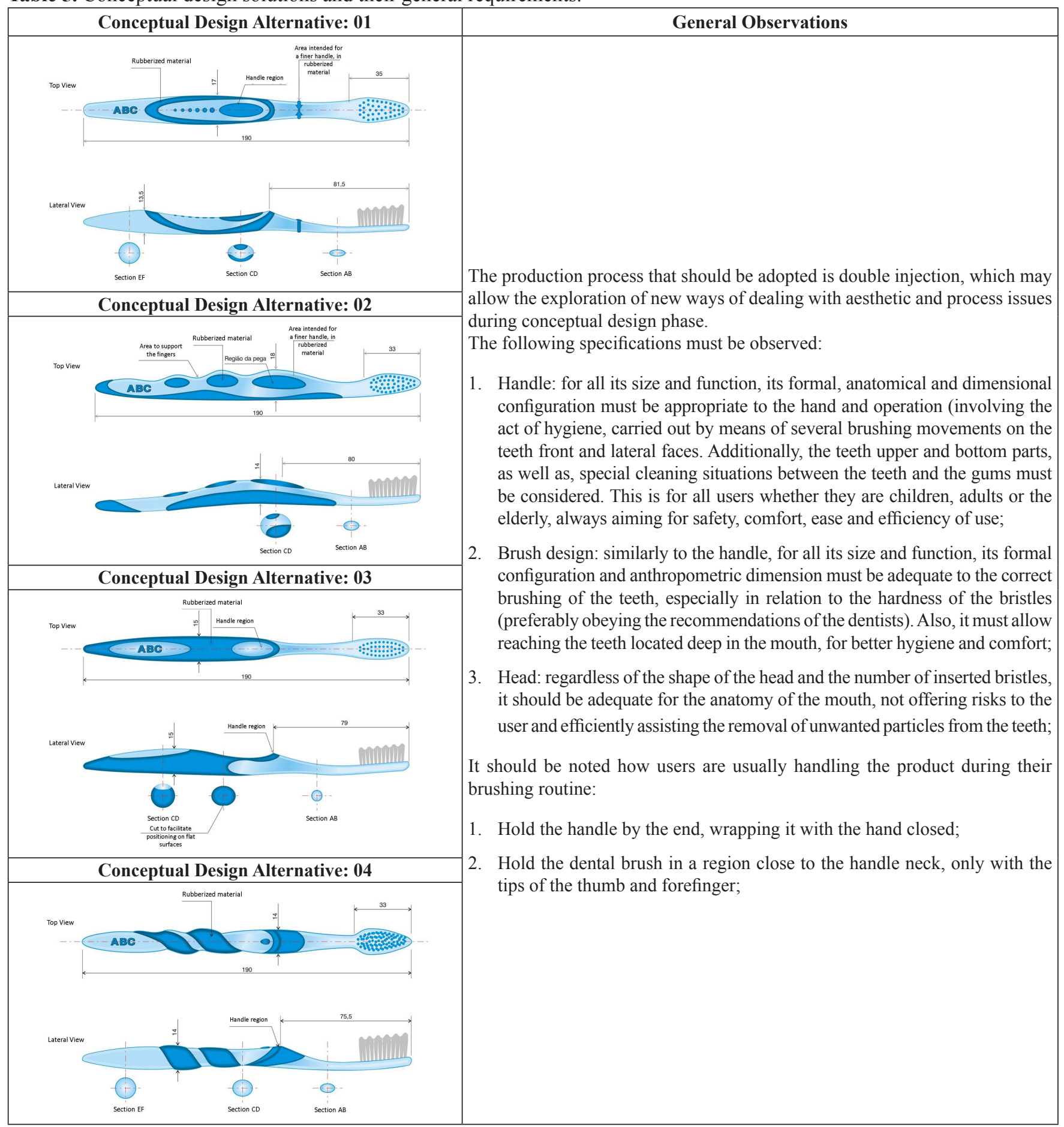

Source: Adapted from Padilha (2008). 
Table 6. Participants profile and respective attributed task to the groups.

\begin{tabular}{|c|c|c|c|}
\hline Group Tag & Composition & Education and Experience & Task \\
\hline \multirow[b]{2}{*}{ G1 } & One professional & Architect and also a Technologist in Furniture & \multirow{2}{*}{$\begin{array}{l}\text { To select the alternative with highest } \\
\text { potential of innovation without the use } \\
\text { API_PC tool }\end{array}$} \\
\hline & One undergraduate student & Student from the Industrial Design Course & \\
\hline G2 & Two undergraduate students & Students from the Industrial Design Course & \multirow{6}{*}{$\begin{array}{l}\text { To select the alternative with highest } \\
\text { potential of innovation with the use } \\
\text { API_PC tool }\end{array}$} \\
\hline \multirow{2}{*}{ G3 } & \multirow{2}{*}{ Two professionals } & Industrial Designer & \\
\hline & & Technologist in Mechanics & \\
\hline \multirow{2}{*}{ G4 } & \multirow{2}{*}{ Two professionals } & Industrial Designer & \\
\hline & & Technologist in Furniture & \\
\hline G5 & One professional & Industrial Designer & \\
\hline
\end{tabular}

Source: Padilha (2008).

group had no access to the API_PC tool information before and during the event. This group should perform the same assigned task (i.e. assess a design solution set and elicit the design solution with the highest innovation potential) as the others based on the method it would think would be most suitable for the design context being examined. All opinions and points of view of the chosen design solution were recorded in writing.

The other groups (called the "experimental groups") remained in the same room and were placed distantly from each other, where a computer was available. There, they received the relevant guidelines regarding the use of the API_PC tool, which was presented in Excel ${ }^{\mathrm{TM}}$ spreadsheet.

After running the experiment, groups G2, G3 and G5, with the support of API_PC tool, indicated that Conceptual Design Alternative: 02 presents the highest innovation potential. On the other hand, group G4 selected Conceptual Design Alternative: 04. For group G3, there was an even result between Conceptual Design Alternative: 02 and Conceptual Design Alternative: 04. In this case (Identical net results derived from the same cells marked), the recommendation indicated in Table 4 is applied: forward the tied design solutions to another assessment tools (e.g. absolute evaluation matrix, relative evaluation matrix).

For G1 (control croup) Conceptual Design Alternative: 04 was selected. The group developed its own evaluation criteria: form, use, differentiation, ergonomics, production process, maintenance. However, their definition was intuitive, without weight values or deploying the criterion into subcriteria.

At the end of the experiment, each participant of the experimental groups filled an evaluation questionnaire, which was divided into three sections: i) familiarity of the participants with the methods of selection of design alternatives at the conceptual design stage; ii) clarity of the objectives set and how was their understanding of the task; and iii) personal assessment about the functionalities of API_PC tool.

The control group answered a similar questionnaire, with a modified third section. The main results are presented next.

\subsection{Observations from participants in the experimental groups}

In section one (familiarization with design and innovation as well as design practices) the questions were related to the experience of the participant with product design activities.

- $100 \%$ of participants already had contact with some type of design methodology;

- The main ways of access to the methodological approaches identified were: training or academic activities (100\%) and academic literature (80\%);

- Participation in product design projects where innovation was part of the requirements: $80 \%$ of the groups answered affirmatively;

- Methods of selecting design alternatives usually applied in practice: check list (80\%) and comparative table $(80 \%)$.

From these data, it is possible to identify that the participants are aware of design methodologies and recognize innovation as a requirement in many of the projects developed. In addition, the respondents highlighted the importance of using methods for selecting design solutions as a mean for supporting the design team decisions.

Section two (clarity of the objectives set and how was their understanding of the task) aimed to identify how the task of selecting design solutions at the conceptual design stage (with and without API_PC tool) was perceived by the groups:

- Understanding the task: $80 \%$ of the participants understood the objectives of the task, which were clearly stated and with the boundaries well defined;

- Understanding of the information supplied to the participants through the proposed design scenario and the conceptual design solutions presented: for most participants $(60 \%)$ the information supplied 
to perform the task was enough and clear. Small doubts in the course of the experiment were promptly resolved.

In section three (assessment about the functionalities of API_PC tool) the participants from groups G2, G3, G4 and $\mathrm{G} 5$ indicated:

- Regarding the interface of the API_PC tool: all participants indicated that the interface devised is suitable for the proposed task. The participant from group G5 suggested the use of a scale with intermediate values (e.g. a design solution could fully, partially or not meet at all a certain subcriterion) when examining a subcriteria. However, in order to avoid any bias from the assessment process, it was assumed the following condition: the proposed conceptual design solution either "fulfils" (thus, a marked cell) or " does not fulfil" (thus, an empty cell) the considered criterion;

- As for the ease of use of the API_PC tool: again, all respondents signalled that API_PC tool is easy to understand and use. Only those participants from group G3 had some questions over the evaluation process to be considered as "absolute" (i.e. each proposed design solution should be examined independently) or relative (a relative comparison between the design alternatives, considering a specific criterion). However, during the experiment these doubts were clarified;

- Regarding the coherence of the criteria addressed in the API_PC tool: all participants manifested that the criteria encompassed by API_PC tool can be mapped to innovation issues. Members from group G3 group mentioned that some of the expressions used for describing certain subcriteria (e.g. "significantly different", "never used before" and "significantly different") clearly address the idea of innovation.

- Considering the conceptual design solution indicated from the results obtained by the API_PC tool considering the participants expectations, $60 \%$ of the respondents answered that the solution indicated fulfilled their expectations;

- The proposition of a tool that assesses innovation in the conceptual stage: all the participants recognized the importance of assessing innovation encapsulated into a design solution during the product development process, in order to drive this process in the quest for differentiated solutions.

Additional remarks collected from the questionnaires:
- There a suggestion that in the future the criterion and subcriterion could be further deployed.

\subsection{Observations from participants in the control group}

For the questionnaire submitted to group G1 (control group) the questions related to the section 3 (API_PC tool) were replaced by inquiring on how the participants addressed the whole conceptual design solutions assessment and selection process. The results obtained were as follows:

- Regarding the identification of the parameters used as the basis for the assessment and selection of the design solution: the parameters highlighted by the respondents were related to the: i) affinities that the specific conceptual design solution encompassed in relation to the design specifications; ii) experience of each participant; and iii) criteria related to innovation established by the group itself, considering the scope of the examined case;

- Regarding the identification of the assumptions adopted by the group in relation to the selection of the alternative with greater innovation potential: the participants mentioned they considered as guidelines in the whole assessment process: i) the aimed set of customers; ii) ergonomics; iii) product usage; and iv) form;

- Regarding the selection of the conceptual design solution itself: after the assessment process, the conceptual design solution selection was performed based on the criteria established by the group and the design scope defined at the beginning of the experiment.

\subsection{Consideration over the whole experiment}

From the observations collected in-loco and from the questionnaires the following remarks can be stated.

- It can be said that API_PC approach (model and tool) allowed the experimental groups to identify, compare, analyse and classify systematically the conceptual design solutions in the set;

- The overall assessment considered weighted values and criteria related to the scope of innovation;

- With this way of assessing conceptual design solutions, API_PC tool allowed the groups to envisage the possibility of working innovation in the initial stages of the product development process;

- Similarly to the previous item, the experiment highlighted the difficulty that many design teams face when selecting alternatives which is that the information at this stage is still quite abstract. 


\section{Final considerations and recommendations for future studies}

Systematizing the design and innovation process makes it possible to identify opportunities that contribute to the improvement of the products developed and, consequently, to the competitiveness of organizations.

The study developed in this work allowed to identify criteria and subcriteria oriented to innovation, reinforcing the idea that innovative solutions should not happen by chance.

The reverse analysis approach envisaged in this work permitted the mapping of a set of criteria that can be considered innovation drivers. The development of the API_PC tool structured these criteria (deploying some of them into subcriteria) and assigned weight values to them.

API_PC tool does not exclude the application of the other evaluation and selection approaches (e.g. Pugh's matrix). Therefore, in certain situations, it can be considered as a checklist of innovation as a first selection process, which can be complemented by other techniques, thus supporting the design team in the decision process.

Participants' perceptions regarding the tool and the criteria it addressed were very positive, which indicates the proposed approach can be utilized.

For future studies it is possible to add new criteria and deploy them into subcriteria, from new reverse analyses performed with other products, as well as, from products from a specific sector (e.g. furniture industry, packaging industry, automotive, amongst others).

\section{References}

BACK, N. et al. Projeto integrado de produtos: planejamento, concepção e modelagem. Barueri: Manole, 2008.

BAGNO, R. B.; LEIVAB, T. L.; OLIVEIRA, L. G. H. Innovation management: lessons learned from innovation diagnostic tools. Product: Management \& Development, v. 14 , n. 1 , p. $12-21,2016$. http://dx.doi.org/10.4322/ pmd.2016.005.

BAXTER, M. Projeto de produto: guia prático para o desenvolvimento de novos produtos. 2. ed. São Paulo: E. Blücher, 2000.

CARVALHO, H. G.; REIS, D. R.; CAVALCANTE, M. B. Gestão da inovação. Curitiba: Aymará, 2011.

CORAL, E.; OGLIARI, A.; ABREU, A. F. Gestão integrada da inovação: estratégia, organização e desenvolvimento de produtos. São Paulo: Atlas, 2008.

LI, W. et al. The process model to aid innovation of products conceptual design. Expert Systems with Applications, v. 37, n. 5, p. 3574-3587, 2010. http://dx.doi.org/10.1016/j. eswa.2009.10.034.
MARINHO, E. S. et al. Relationship between creativity and product innovation: a literature review. Product: Management \& Development, v. 14, n. 1, p. 32-37, 2016. http://dx.doi.org/10.4322/pmd.2016.007.

MUSEU DA CASA BRASILEIRA. Prêmio design. São Paulo, 2014. Available from: <http://www.mcb.org.br/ pt-br/produtos/lavadora-de-alta-pressao-karcher-home-egarden>. Access in: 15 nov 2016.

NANTES, J. F. D.; ABREU, A.; LUCENTE, A. R. The role of technological innovation in the development of new products: a study in the food industries. Product: Management \& Development, v. 4, n. 1, p. 45-52, 2006.

ORGANIZAÇÃO PARA COOPERAÇÃO E DESENVOLVIMENTO ECONÔMICO - OCDE; FINANCIADORA DE ESTUDOS E PROJETOS - FINEP. Manual de Oslo: diretrizes para coleta e interpretação de dados sobre inovação. Tradução FINEP. 3. ed. Paris: OCDE, 2005. Available from: $<$ http://download.finep.gov. br/imprensa/oslo2.pdf $>$. Access in: 18 nov 2016.

PADILHA, J. B. Ferramenta para avaliação de alternativas na etapa conceitual de desenvolvimento de produto: uma abordagem baseada em critérios de inovação. 2008. 145 f. (Mestrado em Engenharia Mecânica e de Materiais) - Programa de Pós-graduação em Engenharia Mecânica e de Materiais, Universidade Tecnológica Federal do Paraná, Curitiba, 2008.

PAHL, G. et al. Projeto na engenharia: fundamentos do desenvolvimento eficaz de produtos, métodos e aplicações. São Paulo: Edgard Blücher, 2005.

PUERTO, H. B. Design e inovação tecnológica: coletânea de idéias para construir um discurso. Salvador: PBD/FIEB/ IEL, 1999.

QUESTTO|NÓ. Projetos. São Paulo, 2015. Available from: <http://www.questtono.com/project/karcherbrasil/?lang=pt $>$. Access in: 12 nov 2016.

ROZENFELD, $H$. et al. Gestão de desenvolvimento de produtos: uma referência para a melhoria do processo. São Paulo: Saraiva, 2006.

SALGADO, E. G. et al. Modelos de referência para desenvolvimento de produtos: classificação, análise e sugestões para pesquisas futuras. Revista Produção Online, v. 10, n. 4, p. 886-911, 2010. http://dx.doi. org/10.14488/1676-1901.v10i4.520.

SARKAR, P.; CHAKRABARTI, A. Assessing design creativity. Design Studies, v. 32, n. 4, p. 348-383, 2011. http://dx.doi.org/10.1016/j.destud.2011.01.002.

SCHERER, F. O.; CARLOMAGNO, M. S. Gestão da inovação na prática: como aplicar conceitos e ferramentas para alavancar a inovação. São Paulo: Atlas, 2009. 
TOH, C. A.; MILLER, S. R. How engineering teams select design concepts: a view through the lens of creativity. Design Studies, v. 38, p. 111-138, 2015. http://dx.doi. org/10.1016/j.destud.2015.03.001.

XIE, X. et al. How does knowledge inertia affect firms product innovation? Journal of Business Research, v. 69, n. 5, p. 1615-1620, 2016. http://dx.doi.org/10.1016/j. jbusres.2015.10.027.

YILMAZ, S.; SEIFERT, C. M. Creativity through design heuristics: A case study of expert product design. Design
Studies, v. 32, n. 4, p. 384-415, 2011. http://dx.doi. org/10.1016/j.destud.2011.01.003.

ZABALA-ITURRIAGAgOITIA, J. M. New product development in traditional industries: decision-making revised. Journal of Technology Management \& Innovation, v. 7 , n. 1, p. 31-51, 2012. http://dx.doi. org/10.4067/S0718-27242012000100003.

ZAWISLAK, P. A. et al. Towards the innovation function. Journal of Technology Management \& Innovation, v. 3, n. 4, p. 17-30, 2008. http://dx.doi.org/10.4067/S071827242008000200002 . 